\title{
SPIRITUALITAS MODERAT SANTRI PONDOK PESANTREN AMANATUL UMMAH KEMBANGBELOR PACET MOJOKERTO
}

\author{
Mohammad Rozi Indrafuddin \\ IAIN Ponorogo \\ indrafuddin@iainponorogo.ac.id
}

\begin{abstract}
Geared under qualitative approach, this research aimed at obtaining information about the forms and reasons for moderate spirituality of the students of the Amanatul Ummah Islamic Boarding School Kembangbelor Pacet Mojokerto. Data was obtained through interviews, observations and literature review. A significant finding from this study is the form of the santri spirituality approach which is internalized in religious, social, scientific, motivational material which is packaged in the seven keys to success and commitment of the Amanatul Ummah students. Some counclusions were made. First, the moderate religious spirituality approach which was internalized at the Boarding School went well proven by efforts to incorporate values and an implementable practice process. Second, the reason for the spirituality of the students leads to the goals and benefits of building religious-nationalist, religious-intellectual and intellectual-religious people, in accordance with Islamic ideals rooted in the Qur'an, al-Sunnah, and Islamic scholars' convention. And finally, spirituality with optimal character through increasing faith, understanding, appreciation, and practice of Islam without forgetting to love the homeland and defend the country.
\end{abstract}

Keywords: moderate spirituality of santri, amanatul ummah Islamic boarding school, religious-nationalist, religious-intellectual, intellectual-religious people

\begin{abstract}
Abstrak
Penelitian ini merupakan penelitian kualitatif yang diarahkan untuk mendapatkan informasi tentang bentuk dan alasan spiritualitas moderat santri Pondok Pesantren Amanatul Ummah Kembangbelor Pacet Mojokerto. Data berupa informasi diambil melalui wawancara, observasi serta kajian pustaka. Temuan signifikan dari penelitian ini adalah bentuk pendekatan spiritualitas santri yang diinternalisasikan dalam materi keagamaan, sosial, sains, motivasional yang dikemas dalam tujuh kunci sukses dan komitmen santri Amanatul Ummah. Kesimpulan penelitian ini, pertama, pendekatan spiritualitas keagamaan moderat yang diinternalisasikan di Pesantren Amanatul Ummah Kembangbelor Pacet Mojokerto berjalan dengan baik dengan bukti adanya upaya memasukkan nilai dan proses pengamalan yang implementatif. Kedua, alasan spiritualitas santri Pondok Pesantren Amanatul Ummah Pacet Mojokerto berujung kepada tujuan dan manfaat demi membangun insan yang religius-nasionalis, religius-
\end{abstract}


intelektualis dan intelektual-religius, sesuai dengan cita-cita Islam yang bersumber pada al-Qur'an, al-Sunnah, dan Ijtihad Ulama. Ketiga, Spiritualitas berkarakter secara optimal melalui peningkatan keimanan, pemahaman, penghayatan, dan pengamalan tentang Islam dan keislaman tanpa melupakan cinta tanah air dan bela negara.

Kata kunci: spiritualitas moderat santri, pondok pesantren amanatul ummah, religius-nasionalis, religius-intelektualis dan intelektual-religius

\section{PENDAHULUAN}

Pondok pesantren perlu dibaca sebagai warisan sekaligus kekayaan kebudayaanintelektual nusantara. Lebih dari itu, pesantren juga harus dipandang sebagai benteng pertahanan kebudayaan karena peran sejarah yang dimainkannya. Sebagai pusat pengembangan ilmu dan budaya yang berdimensi religi dengan improvisasi lokal, pesantren dipersiapkan sebagai motor transformasi bagi masyarakat dan bangsa. Dalam perkembangan sejarah, pesantren memainkan peran yang menonjol dan berpengaruh hingga kini. Berkonsentrasi dalam mempertahankan dan melestarikan ajaran Islam ahlusunnah wa al-jama'ah serta mengembangkan kajian-kajian keagamaan melalui khazanah kitab kuning (al kutub al-qadimah). Sebagai hasil pergulatan kebudayaan yang kreatif antara tradisi kajian, sistem pendidikan, dan pola interaksi kiai-santrimasyarakat sehingga pesantren memiliki pola yang spesifik.

Selaras dengan tuntutan modernitas dan keharusan merespon kenyataan, pesantren pun melakukan perubahan diri. ${ }^{1}$ Terkait dengan itu, adalah penting untuk melihat bagaimana penanaman dan pemahaman atas nilai-nilai pesantren, pola pesantren dalam merespon perubahan. Sebab Pesantren secara umum memiliki dua komitmen utama: sebagai lembaga pendidikan dan lembaga dakwah yang bertujuan untuk mempertahankan bangunan ajaran Islam. ${ }^{2}$ Sebagai lembaga dakwah Islam, ajarannya ditransmisikan melalui proses pengajaran dan pengajian, baik di dalam maupun di luar kelas. Dengan demikian dapat diasumsikan bahwa cara pandang keagamaan para guru, santri dan alumni sangat diwarnai oleh paham keagamaan yang diproduksi oleh kyai pengasuh. Pada gilirannya, cara pandang keagamaan itulah yang

\footnotetext{
${ }^{1}$ Perubahan diri yang dimaksud adalah tetap menjalankan tradisi kepesantrenan klasik yang masih dianggap relevan dan baik, namun tidak menolak untuk mengikuti perkembangan zaman dan menghasilkan sesuatu yang lebih baik. Sesuai dengan kaedah Ushul Fiqh yang senantiasa dijadikan pedoman,$$
\text { المحافظة على قديم الصالح و الاخد بالجديد الاصلح }
$$

menjaga nilai-nilai lama yang baik dan mengambil nilai-nilai baru yang lebih baik.

${ }^{2}$ Nurcholis Madjid, Bilik-bilik Pesantren, Sebuah Potret Perjalanan. Jakarta: Paramadina, 1997), 19.
} 
ditransmisikan ke masyarakat, baik melalui program pengabdian masyarakat maupun sosialisasi yang langsung dilakukan oleh kyai, guru dan santri alumni. Posisi strategis ini menjadikan pesantren sebagai lembaga yang menentukan pemahaman keagamaan di lingkungan masing-masing. Hal ini jelas, karena Islam telah mengajarkan paham moderat, toleran dan berimbang. Maka seorang muslim harus memegang nilai-nilai tradisi lama dan selalu menampakkan sikap kreatif, inovatif dan terlibat aktif dalam menghadapi peradaban baru di kemudian hari.

Berdasarkan pada pandangan tersebut, peneliti tertarik untuk mencermati proses pesantren Amanatul Ummah ${ }^{3}$ dalam menata diri menuju transformasi peradaban umat melalui nilai-nilai ajarannya. Secara umum, persoalan yang diteliti adalah bagaimana Pondok Pesantren Amanatul Ummah sebagai lembaga dakwah Islam dan lembaga pendidikan pesantren dalam pembelajarannya berwawasan moderat, memberikan nilai ubudiyah, bertaqarrub dengan sang pencipta dengan dasar madzhab Ahlusunnah wa al Jama'ah. Dengan meneliti pandangan dan sikap kyai, guru tentang nilai-nilai

\footnotetext{
${ }^{3}$ Pondok Pesantren didirikan oleh Prof. KH. Asep Saifuddin Chalim pada tahun 2006, beliau adalah putra dari KH. Abdul Chalim Leuwimunding Cirebon salah seorang pendiri Nahdlatul Ulama, terletak di desa Kembangbelor Pacet Mojokerto. Setelah sebelumnya didirikan pula di Siwalankerto Surabaya. Adapun visi, misi, tujuan dan peruntukan pondok pesantren Amanatul Ummah adalah sebagai berikut; Visi; mewujudkan manusia yang unggul, utuh dan berakhlaqul karimah untuk kemulyaan dan kejayaan Islam dan kaum muslimin dan terwujudnya cita-cita kemerdekaan bangsa Indonesia yaitu masyarakat yang adil dan makmur. Misi; melaksanakan sistem yang berlaku di Lembaga Pendidikan Unggulan Amanatul Ummah secara ketat dan bertanggung jawab.
}

Tujuan Peruntukan Santri :

1. Menjadi Ulama-ulama besar yang akan bias menerangi dunia dan Indonesia

2. Menjadi para pemimpin dunia dan pemimpin bangsanya yang bisa menegakkan keadilan dan mewujudkan kesejahteraan dan tegaknya keadilan utamanya di Negara Indonesia.

3. Menjadi para konglomerat besar yang bias memberikan kontribusi maksimal terhadap terwujudnya kesejahteraan bangsa Indonesia

4. Menjadi para profesional yang berkualitas dan bertanggung jawab.

Disamping itu terdapat pula tujuh kunci sukses sebagai pegangan kiai, guru dan santri yaitu:

1. Istiqamah bersungguh-sungguh dan ajeg dalam kesungguhan,

2. Menjaga wudlu, setiap santri dan ustad dihimbau untuk selalu melaksanakan wudlu, menjaga dan mempertahankan wudlunya. Ketika batal maka dianjurkan untuk wudlu kembali sehingga kondisi senantiasa suci bersih.

3. Sholat malam, semua santri dan ustad diharuskan melaksanakan sholat malam berjamaah dimulai pada pukul 03.00 sampai waktu Subuh menjelang.

4. Membaca al-Qur'an dengan melihat hurufnya, sebagai bagian untuk mengerti dan memahami kandungan ayat-ayat suci al-Qur'an.

5. Menjauhkan diri dari segala kemaksiatan, bahwa santri dan ustad dilarang melakukan perbuatan maksiat baik yang dilarang oleh agama ataupun yang dilarang oleh norma masyarakat.

6. Tidak boleh jajan sembarangan di luar Pesantren, sebagai antisipasi atas beberapa kejadian yang tidak diinginkan dan menimbulkan unsur negatif.

7. Menjaga kebersihan, sesuai dengan ajaran Islam yang mencintai dan senantiasa menjaga kebersihan. Karena kebersihan prinsipnya adalah menjaga dan mempertahankan keindahan.

Wawancara dengan pengasuh pesantren Amanatul Ummah, Prof. Dr. KH. Asep Saifuddin, 4 Juli 2020. 
kepesantrenan dan spiritualitas, maka penelitian ini memfokuskan pada bagaimana bentuk dan alasan nilai-nilai pesantren yang dijabarkan dalam beberapa hal seperti keikhlasan, kesederhanaan, perjuangan dan ubudiyah, serta pola pendidikan yang berkarakter, seperti pembentukan sikap mandiri, tekun, menjaga kesopanan dan kesusilaan, memupuk kreativitas dan inovasi sehingga menimbulkan suatu proses spiritualitas yang moderat.

\section{METODE PENELITIAN}

Dalam penelitian ini digunakan metodologi penelitian pendekatan kualitatif ${ }^{4}$ dengan karakteristik (a) penelitian kualitatif menggunakan latar alami (natural setting) sebagai sumber data langsung dan peneliti sendiri merupakan instrumen kunci, sedangkan instrumen lain sebagai instrumen penunjang; (b) penelitian kualitatif bersifat deskripstif, data yang dikumpulkan dalam bentuk kata-kata dan gambargambar. $^{5}$

Lokasi penelitian yang dipilih didasarkan pada pertimbangan-pertimbangan dari segi kemenarikan, keunikan dan kegayutan bahwa karakteristik pesantren di Indonesia terbagi menjadi tiga bentuk. ${ }^{6}$ Pertama, pesantren yang cara pendidikan dan pengajarannya menggunakan metode sorogan atau bandongan, yaitu seorang kyai mengajarkan santri-santrinya berdasarkan kitab-kitab klasik yang ditulis dalam bahasa Arab, oleh ulama' abad pertengahan dengan sistem terjemahan. Umumnya pondok pesantren semacam ini "steril" dari ilmu pengetahuan umum biasa disebut dengan nama pesantren salaf. Kedua Pesantren disamping mempertahankan sistem pendidikan dan pengajaran sebagaimana tersebut diatas, juga memasukkan pendidikan umum SD, SMP, SMA, SMK, atau memasukkan sistem madrasah seperti MI, MTs, MA ke pesantren. Ketiga pesantren didalam sistem pendidikan dan pengajarannya mengintegrasikan sistem madrasah ke dalam pesantren dengan segala jiwa, nilai dan

\footnotetext{
${ }^{4}$ Pendekatan kualitatif adalah prosedur penelitian yang menghasilkan data deskriptif berupa kata-kata tertulis atau lisan dari orang-orang dan perilaku yang dapat dialami Lihat dalam Lexy Moleong, Metodologi Penelitian Kualitatif, (Bandung: PT Remaja Rosdakarya, 2000), 3.

${ }^{5}$ Suharsini Arikunto, Prosedur Penelitian Suatu Pendekatan Praktis (Jakarta: Rineka Cipta, 2002), 34.

${ }^{6}$ Mastuhu. "Pesantren dan Ulama Masa Datang", Jurnal Pesantren, Edisi No. 1, Vol. III, 1986.
} 
atribut-atribut lainnya, dan pengajarannya memakai sistem klasikal ditambah dengan disiplin yang ketat dalam asrama atau santri di wajibkan berdiam di asrama. ${ }^{7}$

Data yang dibutuhkan dalam penelitian ini terdiri atas data primer dan data sekunder. Data primer adalah segala informasi yang terkait dengan Pondok Pesantren Amanatul Ummah, mulai dari nilai-nilai pesantren yang diajarkan oleh kyainya, sikap dan peran kyai, ustadz, santri, dan alumninya. Sementara, data sekunder pada prinsipnya mencakup data dokumenter/statistik maupun informasi yang menopang data primer. Sumber data untuk mendapatkan data-data tersebut terbagi menjadi dua: sumber data manusia dan non-manusia. Sumber data manusia terdiri atas kyai, ustadz/ustadzah. Sumber data manusia ini digunakan untuk mendapatkan data-data primer, yaitu cara penanaman nilai-nilai pesantren pada diri santri. Data ini meliputi proses dialogis dalam proses belajar-mengajar. Hasil wawancara dari masing-masing informan ditulis dengan kode dalam transkip wawancara. Dapat dikatakan bahwa dalam penelitian kualitatif jantungnya adalah hasil wawancara dan catatan lapangan. Catatan lapangan pada penelitian ini bersifat deskriptif. Bagian deskriptif tersebut berisi tentang gambar diri fisik, rekonstruksi dialog, deskripsi latar fisik, catatan tentang peristiwa khusus, gambaran kegiatan dan perilaku pengamat. ${ }^{8}$

Pada landasan teori ini, peneliti berupaya mempersiapkan beberapa unit analisis baik dari teori kecil (micro theory), teori menengah (middle range theory), dan teori besar (grand theory). Ketiga imot analisis ini amat diperlukan untuk mengelaborasi fungsi teori sebagai alat penjelas, memprediksi serta merubah fenomena yang ada pada topik penelitian. Secara garis besar, permasalahan dalam penelitian ini diarahkan untuk menggali informasi, amatan dan dokumentasi sebagai bahan untuk dianalisis dalam rangka menjawab fokus penelitian.

\section{HASIL PENELITIAN DAN PEMBAHASAN}

\section{Cara Penanaman Nilai-Nilai Pesantren Pada Diri Santri}

\footnotetext{
${ }^{7}$ Zamakhsyari Dhofier, Tradisi Pesantren: Studi Pandangan Hidup Kyai dan Visinya Mengenai Masa Depan Indonesia. Jakarta : Pustaka LP3ES., 2011.

${ }^{8}$ Ibid, Lexy Moleong, 156.
} 
Cara penanaman nilai-nilai pesantren pada diri santri yang meliputi pengajian yang dilakukan kyai serta pemahaman dan perilaku santri tentang nilai-nilai pesantren. ${ }^{9}$ Peter L Berger dan Thomas Luckmann menegaskan, bahwa dialektika antara internalisasi atau proses memasukkan nilai, objektivasi atau proses dialog dalam diri manusia, serta eksternalisasi atau proses aktualisasi sikap dan tindakan di ruang publik. Teori konstruksi sosial, internalisasi mengandaikan "proses atau ekspresi diri manusia di dalam membangun tatanan kehidupan" atau "proses penyesuaian diri manusia dengan lingkungan-nya". ${ }^{10}$ Pengungkapan diri atau self adjustmen inilah acap berkecenderungan pada diri setiap individu terjadi begitu saja perlahan secara tidak nisbi, mengingat masing-masing elemen dalam interaksi sosial adalah bagian langsung dari realitas sosial. Individu di dalamnya menyadari akan eksistensi sebagai bagian terpenting lingkungannya, bukanlah sebagai penonton yang kurang bermakna. Individu menyadari betapa interaksinya dengan individu lain harus dijaga dan dikondisikan sebaik mungkin. Interaksi sosial dibangun melalui saling menghargai mengingat individu bukanlah infra human yang hanya hidup untuk bertahan secara natural dengan mengekspresikannya melalui pemenuhan kebutuhan biologis semata. Individu merasakan dirinya sebagai supra human yang musti mendahulukan akal pikiran dan perasaannya. ${ }^{11}$ Artinya, pola adaptasi, artikulasi, agregasi, dan objektivasi yang menjadi proses antara internalisasi dan eksternalisasi menjadi sangat penting dalam proses menjadikan individu makin bermakna sebagaimana harapan seluruh entitas individu yang berinteraksi sosial.

1. Temuan dan Analisis Pembahasan

1.1 Selalu ada upaya memasukkan nilai-nilai keagamaan yang sarat dengan arahan dan nasehat. $^{12}$

1.2 Ada perasaan lambat laun santri mulai paham atas nasehat yang diberikan.

Berdasarkan temuan di atas, dapat ditarik preposisi sebagai berikut: Jika ada upaya memasukkan nilai keagamaan dengan cara yang lembut dan perlahan, maka

\footnotetext{
${ }^{9}$ Marwan Saridhi, Sejarah Pesantren di Indonesia (Jakarta: Dharma Bakti, 1982), 8; (Jojuko Prasedjo, et al, Profil Pesantren (Jakarta: LP3S, 1982), 5.

${ }^{10}$ Irwan Abdullah, "Penelitian Berwawasan Gen-der Dalam Ilmu Sosial”, Humaniora, Vol. XV, No. 3, (2003), hlm. 267.

${ }^{11}$ Hanneman Samuel, Perspektif Sosiologis Peter Berger (Jakarta: Pusat Antar Universitas Bidang IlmuIlmu Sosial-Universitas Indonesia, 1993), hlm. 17.

12 Wawancara dengan pengasuh pesantren Amanatul Ummah, Prof. Dr. KH. Asep Saifuddin Chalim, MA., 4 Juli 2020.
} 
proses internalisasi berlangsung dengan baik. Preposisi di atas merupakan análisis secara induktif bahwa proses internalisasi yang ditawarkan oleh Berger Luckmann mendapatkan bukti atas informasi empiris di Pesantren Amanatul Ummah Pacet Mojokerto, artinya teori internalisasi Berger Luckmann mendapatkan konfirmasinya di ranah empiris terutama pada ketersediaan data empiris terkait upaya memasukkan nilai keagamaan yang dislenggarakan secara betahap, lembut dan perlahan.

2. Dialog dalam diri manusia

2.1 Ustadz ikut merenungi nasehat Kyai. ${ }^{13}$

2.2 Santri berdialog untuk melepas ganjalan di hatinya.

Berdasarkan temuan di atas, dapat ditarik preposisi sebagai berikut: Jika ada bukti ustadz yang mau merenungi nasehat Kyai dan diikuti dengan upaya santri untuk selalu berdialog sesamanya, maka proses internalisasi berlangsung dengan baik. Preposisi di atas merupakan análisis secara induktif bahwa proses internalisasi yang ditawarkan oleh Berger Luckmann mendapatkan bukti atas informasi empiris di pesantren Amanatul Ummah Pacet Mojokerto, artinya teori internalisasi Berger Luckmann mendapatkan konfirmasinya di ranah empiris terutama adanya upaya merenungi setiap nasehat Kyai disertai dengan usaha para santri untuk saling mengingatkan dan saling berdialog dalam rangka berkontribusi pada pembentukan karakter berwawasan moderat.

3. Aktualisasi sikap dan tindakan di ruang publik

3.1 Ustadz menegur dan meluruskan santri yang belum menjalankan nasehat Kyai. ${ }^{14}$

3.2 Ustadz dengan hati-hati menjelaskan bagaimana mengamalkan nasehat Kyai.

3.3 Santri tidak ragu untuk mengamalkan apa saja yang didengar dan dilihat. ${ }^{15}$

Berdasarkan temuan di atas, dapat ditarik preposisi sebagai berikut: Jika ada keseriusan ustadz untuk mengawasi perilaku santri apakah sudah mengikuti nasehat Kyai keteguhan santri dalam menjalankan apa yang didengar dan dilihatnya, maka proses internalisasi berlangsung dengan baik. Preposisi di atas merupakan análisis secara induktif bahwa proses internalisasi yang ditawarkan oleh Berger Luckmann mendapatkan bukti atas informasi empiris di pesantren Amanatul Ummah Pacet

\footnotetext{
${ }^{13}$ Wawancara dengan Koordinator Pesantren Amanatul Ummah, Ust. Dr. H. Achmad Chudlori, M.Pd., April 2020.

${ }^{14}$ Ibid

${ }^{15}$ Wawancara dengan santri alumni pesantren Amanatul Ummah, Ahmad Julul Zamzami, 4 Juli 2020.
} 
Mojokerto, artinya teori internalisasi Berger Luckmann mendapatkan konfirmasinya di ranah empiris terutama peran ustadz dalam mengawal nasehat Kyai utuk diamalkan oleh santri, serta terdapatnya upaya santri dalam mengamalkan apa yang didengar dan dilihatnya.

4. Proses atau ekspresi diri manusia di dalam membangun tatanan kehidupan

4.1 Apa yang didapatkan dari pengajian Kyai membekas pada diri alumni santri.

4.2 Santri berharap bahwa selalu ada jalan untuk menyelesaikan mondok dan belajar di pesantren ini.

4.3 Semboyan santri berbunyi sekali mondok ya gak boleh mandek. ${ }^{16}$

Berdasarkan temuan di atas, dapat ditarik preposisi sebagai berikut: Jika ada bekas dari setiap nasehat Kyai dan anggapan bahwa mondok itu selamanya bagi santri, maka proses internalisasi berlangsung dengan baik. Preposisi di atas merupakan análisis secara induktif bahwa proses internalisasi yang ditawarkan oleh Berger Luckmann mendapatkan bukti atas informasi empiris di pesantren Amanatul Ummah Pacet Mojokerto, artinya teori internalisasi Berger Luckmann mendapatkan konfirmasinya di ranah empiris terutama pada anggapan santri untuk tersu mengaji di pesantren meski sudah lulus dari pesantren dan masih membekasnya nasehat Kyai meski santri telah berstatus alumni, serta anggapan serius bahwa menjadi santri pesantren itu adalah selamanya.

5. Proses penyesuaian diri manusia dengan lingkungan-nya

5.1 Proses penyesuaian diri santri dengan lingkungannya bergantung kepada pribadi masing-masing.

5.2 Semua ikut terlibat dalam target proses penyesuaian untuk menanamkan nilai keagamaan dan karakter islami. ${ }^{17}$

Berdasarkan temuan di atas, dapat ditarik preposisi sebagai berikut: Jika proses penyesuaian diri para santri yang bergantung kepada pribadi masing-masing dan penyesuaian itu berujung kepada penanaman nilai keagamaan, maka proses internalisasi berlangsung dengan baik. Preposisi di atas merupakan análisis secara induktif bahwa proses internalisasi yang ditawarkan oleh Berger Luckmann mendapatkan bukti atas informasi empiris di pesantren Amanatul Ummah Pacet 
Mojokerto, artinya teori internalisasi Berger Luckmann mendapatkan konfirmasinya di ranah empiris terutama pada terdapatnya proses penyesuaian diri para yang berdasarkan kepribadian masing-masing santri yang berujung kepada penamaman nilai keagamaan.

6. Pengungkapan diri atau self adjustmen yang berkecenderungan pada diri setiap individu terjadi begitu saja perlahan secara tidak nisbi.

6.1 Kelembutan Kyai dalam bercengkerama dengan asatidz dan santri menjadikan ustadz dan santri makin lembut.

6.2 Penyesuaian dilakukan dengan bertahap, pelan dan berprosedur.

6.2 Santri mengalami pembinaan dan pengontrolan akhlaq secara perlahan. ${ }^{18}$

Berdasarkan temuan di atas, dapat ditarik preposisi sebagai berikut: Jika kelembutan Kyai berimbas kepada kelembutan ustadz dan santri yang berjalan secara perlahan berujung pembinaan akhlaq, maka proses internalisasi berlangsung dengan baik. Preposisi di atas merupakan análisis secara induktif bahwa proses internalisasi yang ditawarkan oleh Berger Luckmann mendapatkan bukti atas informasi empiris di pesantren Amanatul Ummah Pacet Mojokerto, artinya teori internalisasi Berger Luckmann mendapatkan konfirmasinya di ranah empiris terutama pada pengontrolan dan pembinaan akhlaq berkat kelembutan dan ketelatenan Kyai seiring dengan makin lembutnya perangai ustadz dan sekalian santri-santrinya.

7. Individu di dalamnya menyadari akan eksistensinya sebagai bagian terpenting lingkungannya.

7.1 Kami harus menyadari bahwa kami adalah segelintir bagian dari keseluruhan warga pesantren.

7.2 Jiwa korps sesama santri dan alumni amatlah kuat dengan menyadari sebagai bagian tidak terpisahkan.

7.3 Kebersamaan menyampaikan kepada tercapainya Visi, Misi, Tujuan, Peruntukan dan cita-cita pengasuh dalam membentuk santri anak didik yang mampu berkiprah di kesehariannya. ${ }^{19}$

Berdasarkan temuan di atas, dapat ditarik preposisi sebagai berikut: Jika jiwa korps para santri diarahkan kepada rasa tak terpisah sebagai bagian dari kebersamaan

\footnotetext{
${ }^{18}$ Wawancara dengan santri alumni pesantren Amanatul Ummah, Ahmad Dofir, 11 Juli 2020

${ }^{19}$ Ibid.
} 
dan ditujukan demi capaian vivi, misi, tujuan pesantren, maka proses internalisasi berlangsung dengan baik. Preposisi di atas merupakan análisis secara induktif bahwa proses internalisasi yang ditawarkan oleh Berger Luckmann mendapatkan bukti atas informasi empiris di pesantren Amanatul Ummah Pacet Mojokerto, artinya teori internalisasi Berger Luckmann mendapatkan konfirmasinya di ranah empiris terutama adanya jiwa korps para santri yang berdiri sebagai kebersamaan di atas kepentingan individu yang diarahkan kepada tercapainya visi, misi dan tujuan pesantren.

8. Individu menyadari betapa interaksinya dengan individu lain harus dijaga dan dikondisikan sebaik mungkin.

8.1 Koordinator Pesantren mengawal santri dari segi akhlaq dan prestasi melalui hubungan baik

8.2 Ustadz berkeyakinan harus saling mengalah dan berkoreksi diri demi tercapainya tujuan bersama.

8.3 Para ustadz merasakan sebagai sosok pribadi yang harus saling menjaga kebersamaan.

8.4 Santri wajib dan berhak untuk saling mengingatkan dalam memperhatikan kepentingan bersama. ${ }^{20}$

Berdasarkan temuan di atas, dapat ditarik preposisi sebagai berikut: Jika semua civitas pesantren mulai dari koordinator, dewan asatidz dan semua pihak memunculkan saling kebersamaan dan saling mengingatkan satu sama lain demi mencapai tujuan, maka proses internalisasi berlangsung dengan baik. Preposisi di atas merupakan análisis secara induktif bahwa proses internalisasi yang ditawarkan oleh Berger Luckmann mendapatkan bukti atas informasi empiris di pesantren Amanatul Ummah Pacet Mojokerto, artinya teori internalisasi Berger Luckmann mendapatkan konfirmasinya di ranah empiris terutama pada adanya kebersamaan dari seluruh elemen pesantren untuk menuju tercapaianya tujuan pesantren.

9. Saling menghargai

9.1 Karena seringnya disampaikan, santri selalu saling menghargai dan santri pondok pesantren itu wajib saling menghargai.

\footnotetext{
${ }^{20}$ Wawancara dengan Koordinator Penanggung jawab Pesantren Amanatul Ummah, Ust. Dr. H. Achmad Chudlori, M.Pd., 4 Juli 2020.
} 
9.2 Menghargai orangtua, guru dan siapapun yang ada di sekita santri. ${ }^{21}$

Berdasarkan temuan di atas, dapat ditarik preposisi sebagai berikut: Jika saling menghargai itu dibudayakan, maka proses internalisasi berlangsung dengan baik. Preposisi di atas merupakan análisis secara induktif bahwa proses internalisasi yang ditawarkan oleh Berger Luckmann mendapatkan bukti atas informasi empiris di pesantren Amanatul Ummah Pacet Mojokerto, artinya teori internalisasi Berger Luckmann mendapatkan konfirmasinya di ranah empiris terutama pada terwujudnya sikap saling menghargai di antara elemen pesantren.

10. Proses menjadikan individu makin bermakna.

10.1 Beberapa ustadz juga sudah menyandang gelar doktor dan cukuplah menjadi penyemangat santri untuk memikirkan dan menyiapkan bekal agar hidupnya bermakna dengan mengikuti anjuran Kyai dan pengurus di pesantren ini

10.2 Kalimat yang sering diucapkan oleh Koordinator Pesantren tentang pemenuhan harapan bermakna bagi orang lain menjadi kata magis bagi santri

10.3 Dalil tentang orang yang berguna adalah orang yang paling bermanfaat bagi orang lain bukan hanya di mulut saja. Lingkungan pesantren amat berskala besar dalam menerapkan dan mengamalkan petuah ini

Berdasarkan temuan di atas, dapat ditarik preposisi sebagai berikut: Jika terbukti adanya proses pembelajaran menuju proses hidup bermakna, maka proses internalisasi berlangsung dengan baik. Preposisi di atas merupakan análisis secara induktif bahwa proses internalisasi yang ditawarkan oleh Berger Luckmann mendapatkan bukti atas informasi empiris di pesantren Amanatul Ummah Pacet Mojokerto, artinya teori internalisasi Berger Luckmann mendapatkan konfirmasinya di ranah empiris terutama pada adanya proses pembelajaran yang menuju kepada pembelajaran yang bermakna.

11. Harapan seluruh entitas individu yang berinteraksi sosial.

11.1 Bacaan-bacaan penyemangat berproyeksi pada sasaran akhir yakni harapan besar dari cita-cita besar yang dicanangkan Kyai.

11.2 Harapan santri sebetulnya hanya ingin patuh kepada orang tua saja.

11.3 Apa yang dijalani santri yang pernah mondok di pesantren ini senantiasa didasarkan kepada harapan pribadinya agar tidak merepotkan di kemudian hari. ${ }^{22}$

\footnotetext{
${ }^{21}$ Wawancara dengan santri alumni pesantren Amanatul Ummah, Jeffa Lianto Van Bee, April 2020, 11 Juli 2020.

${ }^{22}$ Wawancara dengan santri alumni pesantren Amanatul Ummah, Ahmad Dofir, 11 Juli 2020.
} 
Berdasarkan temuan di atas, dapat ditarik preposisi sebagai berikut: Jika harapan santri dan alumni pesantren terpenuhi, maka proses internalisasi berlangsung dengan baik. Preposisi di atas merupakan análisis secara induktif bahwa proses internalisasi yang ditawarkan oleh Berger Luckmann mendapatkan bukti atas informasi empiris di pesantren Amanatul Ummah Pacet Mojokerto, artinya teori internalisasi Berger Luckmann mendapatkan konfirmasinya di ranah empiris terutama pada adanya pemenuhan harapan pada diri santri, alumni santri, wali santri dan seluruh civitas di pesantren Amanatul Ummah Pacet Mojokerto.

\section{Pembelajaran dan Pendidikan Berwawasan Moderat Pondok Pesantren Amanatul Ummah}

Fokus Penelitian: Pembelajaran dan pendidikan yang berwawasan moderat Pondok Pesantren Amanatul Ummah meliputi hal-hal yang berkaitan dengan tujuan pendidikan pesantren, kurikulum, metode pembelajaran, serta sistem evaluasi kegiatan penunjang. Muhaimin dan Mujib mendefinisikan pendidikan agama Islam yang berwawasan moderat sebagai suatu sistem pendidikan yang memungkinkan seseorang dapat mengarahkan kehidupannya sesuai dengan cita-cita Islam, sehingga dengan mudah ia membentuk hidupnya sesuai dengan ajaran Islam. Definisi ini mengacu pada perkembangan kehidupan manusia masa depan, tanpa menghilangkan prinsip-prinsip Islam2 yang diamanatkan Allah SWT kepada manusia, sehingga manusia mampu memenuhi kebutuhan dan tuntutan hidupnya, seiring dengan perkembangan ilmu pengetahuan dan teknologi. ${ }^{23}$

Susan \& Munir menegaskan bahwa asal usul dari term pendidikan Islam yang berwawasan moderat ini memiliki banyak arti, yang meliputi pendidikan Islam sebagai upaya yang dilakukan oleh masyarakat Islam untuk mendidik dirinya dalam rangka menyampaikan warisan pengetahuan dan ilmu ke-Islam-an melalui sumber utamanya yaitu al-Qur'an dan al-Sunnah. Sentra pendidikannya lazim bertumpu di Masjid, madrasah dan sekolah, institusi Perguruan Tinggi, dan lembaga-lembaga organisasi yang diberdayaupayakan oleh umat Islam. Ada empat tipe dari pendidikan Islam, yakni pendidikan dari orang Islam di dalam keyakinan Islam mereka; pendidikan untuk orang Islam yang memasukkan disiplin ilmu agama dan sekuler; pendidikan tentang Islam

${ }^{23}$ Muhamin \& Mujib, Pemikiran Pendidikan Islam, (Jakarta: Tri Genda Karya: 1993), 134. 
bagi mereka yang bukan muslim; dan pendidikan di dalam semangat dan tradisi Islam. $^{24}$

Mudawi menambahkan pendidikan Islam yang berwawasan moderat bercirikan kepada tipe pendidikan berdasarkan ideologi Islam dan meliputi seperangkat kebijakan pendidikan dan bimbingan yang diatur melalui proses Islamisasi masyarakat dan upaya memajukan serta berkecenderungan kepada modernisasi. ${ }^{25}$ Pendidikan Islam itu dilandaskan kepada Ideologi atau cita-cita Islam yang berkecenderungan kepada penciptaan kepribadian yang Islami. Zakiah Daradjat mengelaborasi pentingnya dasar pendidikan Islam yang berwawasan moderat meliputi al-Qur'an, al-Sunnah, dan ijtihad. ${ }^{26}$

Temuan dan Analisis Pembahasan

1. Mengarahkan kehidupannya sesuai dengan cita-cita Islam

1.1 Wakil bidang kepesantrenan wajib menjaga garis kebijakan Kyai dalam memberikan layanan pendidikan di pesantren ini dengan dasar haluan ahlu sunnah wal jamaah.

1.2 Santri sadar, belajar dan menjalankan agama Islam itu harus penuh kasih sayang dan lembut.

1.3 Kyai mendefinisikan Islam itu sesuatu yang lembut. ${ }^{27}$

Berdasarkan temuan di atas, dapat ditarik preposisi sebagai berikut: Jika ada layanan pendidikan, kesadaran untuk belajar islam dan pendefinisian islam sebagai sesuatu yang lembut maka pendidikan berwawasan moderat berjalan dengan signifikan.

Preposisi di atas merupakan análisis secara induktif bahwa pendidikan berwawasan moderat yang ditawarkan oleh Muhaimin dan Mujib mendapatkan bukti atas informasi empiris di pesantren Amanatul Ummah Pacet Mojokerto, artinya teori pendidikan berwawasan moderat oleh Muhaimin dan Mujib mendapatkan konfirmasinya di ranah empiris terutama adanya layanan pendidikan disertai kesadaran belajar agama Islam dengan pendefinisian yang lembut.

\footnotetext{
${ }^{24}$ Susan \& Munir, "Defining Islamic Education: Differenciation and Applications." Current Issues in Comparative Education, Vol. 7 (1), 8.

${ }^{25}$ Mudawi, 'Islamic Education: Towards A Comprehensive View.' King Saud University., Vol. 1 Educ. Sci. (1,2), 9.

${ }^{26}$ Zakiah Daradjat, Ilmu Pendidikan Islam, (Jakarta: Bumi Aksara, 1992), 19-20.

${ }^{27}$ Wawancara dengan santri Wakil kepesantren Amanatul Ummah, Ust. Abdul Halim, M.Pd, 4 Juli 2020.
} 
2. Mengacu pada perkembangan kehidupan manusia masa depan, tanpa menghilangkan prinsip-prinsip Islam.

2.1 Belajar sains itu harus diniatkan untuk mensyukuri bukti kekuasaan Allah. Proyeksi masa depan itu letaknya bukan di pengetahuan dan teknologi, namun harus berproyeksi kepada penyiapan bekal untuk kehidupan yang akan datang

2.1 Pesantren yang masih menjaga tradisi para pendahulu sekaligus menjadikannya sebagai pelajaran untuk masa sekarang (mode), maka untuk kepentingan masa depan hanyalah sebatas seberapa besar dan banyak bekal yang disiapkan untuk kehidupan abadi kelak di sisi Allah

2.3 Tetap menjalankan al-Quran dan hadits seraya selalu memohon petunjuk atas semua yang akan dilakukan dan diamalkan. Ilmu dan hikmah harus disertakan dalam setiap nafas kita. ${ }^{28}$

Berdasarkan temuan di atas, dapat ditarik preposisi sebagai berikut:

Jika pesantren masih menjaga tradisi ulama salaf dan menguasakan pendidikan kekinian serta berproyeksi kepada pembekalan untuk hidup masa depan berdasarkan ilmu dan himah, maka pendidikan berwawasan moderat berjalan dengan signifikan. Preposisi di atas merupakan análisis secara induktif bahwa pendidikan berwawasan moderat yang ditawarkan oleh Muhaimin dan Mujib mendapatkan bukti atas informasi empiris di pesantren Amanatul Ummah Pacet Mojokerto, artinya teori pendidikan berwawasan moderat oleh Muhaimin dan Mujib mendapatkan konfirmasinya di ranah empiris terutama pada tetapnya pada tradisi ulama salaf dan konsern pada kekinian berikut mepersiapkan bekal akhirat berdasarkan ilmu dan hikmah.

3. Mampu memenuhi kebutuhan dan tuntutan hidupnya, seiring dengan perkembangan ilmu pengetahuan dan teknologi.

3.1 Harapan itu tidak akan sisa-sia manakala selalu mengikuti dan patuh nasehat orangtua dan guru.

3.2 Harapan alumni insyaAllah sudah terpenuhi berkat kegigihan orangtua dan para guru di pesantren tentunya.

3.3 Di era teknologi, pesantren tanggap dalam menjawab tantangan jaman sekaligus tidak tergopoh meninggalkan warisan ulama terdahulu. ${ }^{29}$

\footnotetext{
${ }^{28}$ Wawancara dengan santri alumni pesantren Amanatul Ummah, Jeffa Lianto Van Bee, 11 Juli 2020.

${ }^{29}$ Wawancara dengan Ahmad Dofir.
} 
Berdasarkan temuan di atas, dapat ditarik preposisi sebagai berikut :

Jika pemenuhan harapan orangtua dan guru disertai dengan upaya pesantren untuk tanggap dalam menjawab tantangan jaman, maka pendidikan berwawasan moderat berjalan dengan signifikan. Preposisi di atas merupakan análisis secara induktif bahwa pendidikan berwawasan moderat yang ditawarkan oleh Muhaimin dan Mujib mendapatkan bukti atas informasi empiris di pesantren Amanatul Ummah Pacet Mojokerto, artinya teori pendidikan berwawasan moderat oleh Muhaimin dan Mujib mendapatkan konfirmasinya di ranah empiris terutama dengan terdapatnya pemenuhan harapan orangtua dan guru disertai dengan upaya pesantren dalam menjawab tantangan jaman.

4. Menyampaikan warisan pengetahuan dan ilmu ke-Islam-an

4.1 Ulama itu pewaris Nabi Muhmmad. Siapapun yang mewarisi dan mewariskan ilmunya Nabi Muhammad maka ialah yang pantas disebut ulama. Spirit inilah yang selalu dipegang pengasuh untuk memenuhi kegiatan mengaji santri.

4.2 Lingkungan pesantren pada kelas diniyah, pengajian kitab kuning menjadi menu utama setiap santri. Muaranya adalah memberi pengalaman belajar dalam keilmuan dan amaliyah hingga berharap berada pada ilahiyat cinta Allah.

4.3 Kebanyakan ulama yang diundang adalah ulama berhaluan ahlu sunnah wal jamaah yang mengajarkan nilai jalan tengah atau moderat. ${ }^{30}$

Berdasarkan temuan di atas, dapat ditarik preposisi sebagai berikut :

Jika pesantren berkukuh kepada pewarisan ilmu ulama dengan mentransferkannya kepada santri untuk memberi pengalaman belajar atas dasar haluan ahlu sunnah wal jamaah, maka pendidikan berwawasan moderat berjalan dengan signifikan. Preposisi di atas merupakan análisis secara induktif bahwa pendidikan berwawasan moderat yang ditawarkan oleh Susan dan Munir mendapatkan bukti atas informasi empiris di pesantren Amanatul Ummah Pacet Mojokerto, artinya teori pendidikan berwawasan moderat oleh Susan dan Munir mendapatkan konfirmasinya di ranah empiris terutama pada pemberian pengalaman belajar kepada santri oleh ulama ahlu sunnah wal jamaah.

2. Bertumpu di Masjid, madrasah dan sekolah.

30 Wawancara dengan santri alumni pesantren Amanatul Ummah, Alfian Nur Muhammad, 11 Juli 20202020. 
2.1 Pesantren ini sedang dan telah menjalani model pendidikan Islam yang sudah dirntis oleh para ulama pendahulu.

2.2 Pesantren ini mewarisi tradisi pendidikan Islam yang berwawasan karakter dan berwawasan moderat dengan keberadaan masjidnya.

2.3 Banyak kenangan bagi santri di masjid apalagi di bulan ramadhan. ${ }^{31}$

Berdasarkan temuan di atas, dapat ditarik preposisi sebagai berikut: Jika pewarisan ilmu ulama terdahulu diselenggarakan di masjid atau madrasah, maka pendidikan berwawasan moderat berjalan dengan signifikan. Preposisi di atas merupakan análisis secara induktif bahwa pendidikan berwawasan moderat yang ditawarkan oleh Susan dan Munir mendapatkan bukti atas informasi empiris di pesantren Amanatul Ummah Pacet Mojokerto, artinya teori pendidikan berwawasan moderat oleh Susan dan Munir mendapatkan konfirmasinya di ranah empiris terutama pada pewarisan ilmu ulama disertai dengan penyelenggaraan penddidkan agma Islam melalui masjid dan madrasah.

3. Pendidikan dari orang Islam dalam keyakinan Islam.

3.1 Pesantren ini diperuntukkan bagi santri yang beragama Islam. Belum ada santri kami yang beragama selain Islam.

3.2 Santri beragam, tapi mereka semua muslim. ${ }^{32}$

Berdasarkan temuan di atas, dapat ditarik preposisi sebagai berikut: Jika pendidikan diperuntukkan kepada santri muslim semata meski beragam asal dan gaya belajarnya, maka pendidikan berwawasan moderat berjalan dengan signifikan. Preposisi di atas merupakan análisis secara induktif bahwa pendidikan berwawasan moderat yang ditawarkan oleh Susan dan Munir mendapatkan bukti atas informasi empiris di pesantren Amanatul Ummah Pacet Mojokerto, artinya teori pendidikan berwawasan moderat oleh Susan dan Munir mendapatkan konfirmasinya diranah empiris terutama pada pemberian pengalaman belajar kepada santri muslim meski mereka beragam dalam gaya dan hasil belajarnya.

1. Berdasarkan ideologi Islam

1.1 Ideologi Islam yang dijalankan di pesantren adalah pandangan atau gagasan yang dibawa oleh Nabi Muhammad.

${ }^{31}$ Ibid.

32 Wawancara dengan pengasuh pesantren Amanatul Ummah, Prof. Dr. KH. Asep Saifuddin Chalim, MA., 4 Juli 2020. 
1.2 Islam adalah agama yang datangnya dari Allah dan bagaimana mau disebut ideology kalau islam itu benar-benar agama atau aturan yang turun dari Allah Tuhan semesta alam. ${ }^{33}$

Berdasarkan temuan di atas, dapat ditarik preposisi sebagai berikut: Jika pesantren menerapkan pembelajaran agama Islam yang benar-benar dibawa oleh Nabi Muhammad berisi aturan yang diturunkan dari Allah, maka pendidikan berwawasan moderat berjalan dengan signifikan. Preposisi di atas merupakan análisis secara induktif bahwa pendidikan berwawasan moderat yang ditawarkan oleh Mudawi mendapatkan bukti atas informasi empiris di pesantren Amanatul Ummah Pacet Mojokerto, artinya teori pendidikan berwawasan moderat oleh Mudawi mendapatkan konfirmasinya di ranah empiris terutama pada pemberian pengalaman belajar kepada santri oleh ulama ahlu sunnah wal jamaah.

2. Berkecenderungan kepada modernisasi

2.1 Pengasuh atau Kyai sebetulnya tidak berkenan dengan sebutan modern itu. Beliau masih tetap menganggap pesantrennya bercorak salaf namun memberikan layanan secara kekinian

2.2 Gedungnya biasa, tidak megah dan tidak kumuh tetapi ada kelas. ${ }^{34}$

Berdasarkan temuan di atas, dapat ditarik preposisi sebagai berikut: Jika pesantren bercorak salaf namun memberikan layanan kekinian, maka pendidikan berwawasan moderat berjalan dengan signifikan. Preposisi di atas merupakan análisis secara induktif bahwa pendidikan berwawasan moderat yang ditawarkan oleh Mudawi mendapatkan bukti atas informasi empiris di pesantren Amanatul Ummah Pacet Mojokerto, artinya teori pendidikan berwawasan moderat oleh Mudawi mendapatkan konfirmasinya di ranah empiris terutama pada tetap melihat corak tradsi namun tetap memberi layanan kekinian.

3. Al-Qur'an, al-Sunnah, dan ijtihad

3.1 Mereka mengajarkan hal-hal Islami seperti al-Quran Hadits beserta Tafsir penjelasannya, fiqih dengan segala ushulnya, dan seterusnya.

33 Ibid.

${ }^{34}$ Wawancara dengan Koordinator Pesantren Amanatul Ummah, Ust. Dr. H. Achmad Chudlori, M.Pd., 4 Juli 2020. 
3.2 Kami diberi masalah dan kami harus menyelesaikan masalahnya termasuk memberikan ta'bir atau referensi penjelasan secara fiqiyah. ${ }^{35}$

Berdasarkan temuan di atas, dapat ditarik preposisi sebagai berikut: Jika pesantren mengajarkan konten alquran hadits dan ijthad, maka pendidikan berwawasan moderat berjalan dengan signifikan. Preposisi di atas merupakan análisis secara induktif bahwa pendidikan berwawasan moderat yang ditawarkan oleh Zakiah Daradjat mendapatkan bukti atas informasi empiris di pesantren Amanatul Ummah Pacet Mojokerto, artinya teori pendidikan berwawasan moderat oleh Zakiah Daradjat mendapatkan konfirmasinya di ranah empiris terutama pada adanya pemberian konten alquran hadits dan ijtihad.

\section{Pendidikan Berkarakter Santri Pondok Pesantren Amanatul Ummah}

Fokus Penelitian; Pendidikan berkarakter yang meliputi Kegiatan santri di luar kelas beserta pembiasaan-pembiasaan.

Pada galibnya, pendidikan agama Islam yang berkarakter beresolusi pada peningkatan keimanan, pemahaman, penghayatan, dan pengamalan anak didik atau santri atau pembelajar tentang agama Islam, sehingga menjadi manusia muslim yang beriman dan bertaqwa kepada Allah SWT serta berakhlak mulia dalam kehidupan pribadi, bermasyarakat, berbangsa dan bernegara. Dengan demikian, dimensi yang menjadi kenicayaan pada aktivitas pembelajaran pendidikan agama Islam, meliputi (1) dimensi keimanan santri terhadap ajaran Islam, (2) dimensi pemahaman dan penalaran (intelektual) serta keilmuan santri terhadap ajaran Islam, (3) dimensi penghayatan atau pengalaman batin yang dirasakan santri dalam menjalankan ajaran Islam, (4) dimensi pengamalannya, dalam arti bagaimana ajaran Islam yang telah diimani, dipahami dan dihayati atau diinternalisasikan oleh santri itu mampu menumbuhkan motivasi dalam dirinya untuk menggerakkan, mengamalkan, dan mentaati ajaran agama Islam dan nilai-nilainya dalam kehidupan pribadi, sebagai manusia yang beriman dan bertaqwa kepada Allah SWT serta mengaktualisasikannya dalam kehidupan bermasyarakat, berbangsa dan bernegara. ${ }^{36}$

\footnotetext{
${ }^{35}$ Wawancara dengan santri alumni pesantren Amanatul Ummah, Alfian Nur Muhammad, 11 Juli 2020.

${ }^{36}$ Muhaimin, Paradigma Pendidikan Islam, (Bandung: Rosdakarya, 2001), 78.
} 
Maimun \& Ismail, pendidikan yang berkarakter harus bertumpu pada konstruk yang meliputi 1) pendidikan sepanjang hayat. 2) totalitas kepada potensi jiwa, pikiran dan tubuh yang tersinergis pada tiga ranah kognitif, afektif dan psikomotor. 3) spirit dalam menjalankan tugas dan kewajiban sebagai makhluq ciptaan Tuhan sekaligus ekspresi diri sebagai pemimpin di muka bumi, serta juga menjadikan diri sebagai insan yang sholihin untuk kehidupan kelak yang lebih abadi di sisi Tuhan. ${ }^{37}$

Mahmood dan Khan menyebut resolusi atau target pendidikan Islam yang berkarakter harus berorientasi untuk makin dekat atau taqorub kepada Tuhan serta untuk menjadikan hidup makin sadar. Tujuh kualitas yang harus diinternalisasikan kepada anak didik yang meliputi 1) keimanan, 2) keyakinan pada diri sendiri, 3) kejujuran, 4) kebenaran, 5) amanah (dapat dipercaya), 6) motivasi dan 7) kasih sayang. ${ }^{38}$ Ekspresi dan perfoman penampilan moral wajib mengemuka dalam aspek personal dan professional baik sebagai diri, anggota masyarakat sekaligus bagian dari subjeknya dalam berbangsa dan bernegara.

Temuan dan Analisis Pembahasan

1. Peningkatan keimanan, pemahaman, penghayatan, dan pengamalan anak didik atau santri atau pembelajar tentang agama Islam

1.1 Praktek keagamaan menjadi sangat penting bagi kami. Materi ajar yang diserap tidak cukup hanya dinilai dari hasil beljar secara kognitif belaka, namun dilihat bagaimana santri bisa mengamalkan dan merapkannya sebagai pengalaman dan pengamalan sehari.

1.2 Di masjid inilah saya mengamalkan setiap materi ajar yang diberikan oleh para ustadz. Iman dan penghayatan itu omong kosong kalau tidak diamalkan. ${ }^{39}$

1.3 Sepandai apapun santri secara kognitif, akan sia-sia dalam kesehariannya bila tidak dibarengi dengan pembentukan akhlaq yang baik, dan itu terlihat pada ketrampilan santri dalam mempraktekkan ilmunya pada kesehariannya.

Berdasarkan temuan di atas, dapat ditarik preposisi sebagai berikut: Jika pesantren memberi pemahaman, pengalaman, pengamalan, penghayatan, dan penerapan dalam pendidikan agama Islamnya, maka pendidikan berkarakter berjalan

\footnotetext{
37 Maimun \& Ismail, Integrated Islamic Education in Brunei Darussalam: The Hope and the Chalange. Educare (2009), 142.

38 Mahmood \& Khan,'Moral Development in Mystical Islamic Education in Indo-Pak Subcontinent: Sufism'. Journal of Education and Sociology, (2010), 5.

${ }^{39}$ Wawancara dengan santri alumni pesantren Amanatul Ummah, Varicha Fiddarain, 11 Juli 2020.
} 
dengan optimal. Preposisi di atas merupakan análisis secara induktif bahwa pendidikan berkarakter yang ditawarkan oleh Muhaimin mendapatkan bukti atas informasi empiris di pesantren Amanatul Ummah Pacet Mojokerto, artinya teori pendidikan berkarakter oleh Muhaimin mendapatkan konfirmasinya di ranah empiris terutama pada adanya pemberian pemahaman, pengalaman, pengamalan, penghayatan dan penerapan pada setiap praktek keagamaan yang dijalankan oleh santri.

2. Mengaktualisasikannya dalam kehidupan bermasyarakat, berbangsa dan bernegara.

2.1 Haluan aqidah, ibadah dan tasawuf ahlu sunnah wal jamaah yang menjadi spirit ibadah di pesantren ini sedini mungkin diajarkan dan dibekalkan kepada santri.

2.2 Mendengar saya dari pesantren, saya sering diminta untuk menjadi imam sholat. Bersyukur dulunya saya pernah belajar di pesantren.

2.3 Santri bisa mengislamkan teman kuliah yang berasal dari Rusia. ${ }^{40}$

Berdasarkan temuan di atas, dapat ditarik preposisi sebagai berikut: Jika pesantren membekali santri dengan ajaran aqidah, tasawuf dan fiqih berhaluan ahlu sunnah wal jamaah, maka pendidikan berkarakter berjalan dengan optimal. Preposisi di atas merupakan análisis secara induktif bahwa pendidikan berkarakter yang ditawarkan oleh Muhaimin mendapatkan bukti atas informasi empiris di pesantren Amanatul Ummah Pacet Mojokerto, artinya teori pendidikan berkarakter oleh Muhaimin mendapatkan konfirmasinya di ranah empiris terutama pada adanya pemberian pemahaman, pengalaman, pengamalan, penghayatan dan penerapan pada setiap praktek keagamaan yang dijalankan oleh santri, sekaligus memberikan pembekalan dengan ajaran aqidah, tasawuf dan fiqih berhaluan ahlu sunnah wal jamaah.

1. Pendidikan sepanjang hayat

1.1 Pahala dan kedudukan thulab atau murid sangat mulia, karena memang belajar itu wajibnya harus sepanjang hayat.

1.2 Setidaknya belajar yang baik itu memang sejak di buaian ibu hingga di liang lahad.

1.3 Santri tidak mau kehilangan suasana mengaji meski sduah lulus kuliah dan bekerja karena bagi saya mengaji dan menutut ilmu agama itu sampai kapanpun.

40 Wawancara melalui aplikasi media sosial dengan santri alumni pesantren Amanatul Ummah, Ihdan Muhammad Zaki yang melanjutkan kuliah di Rusia, 25 Juli 2020. 
1.4 Harapan saya selain hafal alquran, saya ingin menjadi hamba Allah yang sholihin. Orangtua selalu mendokan saya. Sesekali saya sowan abah Kyai untuk nyuwun doa restu beliau agar saya menjadi anak yang sholih. ${ }^{41}$

Berdasarkan temuan di atas, dapat ditarik preposisi sebagai berikut: Jika pesantren mengenalkan pendidkan sepanjang hayat, maka pendidikan berkarakter berjalan dengan optimal. Preposisi di atas merupakan análisis secara induktif bahwa pendidikan berkarakter yang ditawarkan oleh Maimun dan Ismail mendapatkan bukti atas informasi empiris di pesantren Amanatul Ummah Pacet Mojokerto, artinya teori pendidikan berkarakter oleh Maimun dan Ismail mendapatkan konfirmasinya di ranah empiris terutama pada adanya pemberian pembelajaran sepanjang hayat.

Makin dekat kepada Allah serta untuk menjadikan hidup semakin sadar.

1.1 Setiap praktek keagamaan yang diwajibkan kepada santri selalu diiringi dengan pemotivasian dengan mencontohkan alumni yang telah terlebih dahulu memperoleh manfaat dari praktek keagamaannya.

1.2 Di saat yang menyiksa batin saya itu, saya didatangi oleh ustadz saya untuk pasrah kepada Allah dan menyerahkan semuanya kepadaNya. ${ }^{42}$

Berdasarkan temuan di atas, dapat ditarik preposisi sebagai berikut: Jika praktek keagamaan diarahkan semata-mata pasrah taqorub ilAllah, maka pendidikan berkarakter berjalan dengan optimal. Preposisi di atas merupakan análisis secara induktif bahwa pendidikan berkarakter yang ditawarkan oleh Mahmood dan Khan mendapatkan bukti atas informasi empiris di pesantren Amanatul Ummah Pacet Mojokerto, artinya teori pendidikan berkarakter oleh Mahmood dan Khan mendapatkan konfirmasinya di ranah empiris terutama pada adanya pemberian pembelajaran berupa praktek keagamaan yang ditujukan untuk Allah semata.

2. Ekspresi dan perfoman penampilan moral wajib mengemuka dalam aspek personal dan professional baik sebagai diri, anggota masyarakat sekaligus bagian dari subjeknya dalam berbangsa dan bernegara.

2.1 Santri harus dibekali kompetensi yang utuh baik sebagai pribadi, bagian dari entitas sosial, mampu mengajak teman sebaya untuk menuntaskan pembelajarannya, serta santri itu wajib menjaga profesinya sebagai santri yang harus tekun belajar dan

${ }^{41}$ Wawancara dengan santri alumni pesantren Amanatul Ummah, Ahmad Dofir, 11 Juli 2020.

${ }^{42}$ Ibid. 
mengaji. Inilah mungkin yang menjadi pemotivasian Kyai kepada kami para asatidz dalam mengawal santri dalam mengaji dan belajarnya di pesantren. ${ }^{43}$

2.2 Santri dan alumni pesantren sama-sama mendapatkan perhatian yang lebih. ${ }^{44}$

Berdasarkan temuan di atas, dapat ditarik preposisi sebagai berikut: Jika praktek keagamaan diarahkan pada pembekalan secara personal, sosial, pedagogik dan profesional kepada santri, maka pendidikan berkarakter berjalan dengan optimal. Preposisi di atas merupakan análisis secara induktif bahwa pendidikan berkarakter yang ditawarkan oleh Mahmood dan Khan mendapatkan bukti atas informasi empiris di pesantren Amanatul Ummah Pacet Mojokerto, artinya teori pendidikan berkarakter oleh Mahmood dan Khan mendapatkan konfirmasinya di ranah empiris terutama adanya pemberian pembelajaran praktek keagamaan yang ditujukan untuk Allah semata, dengan berorientasi kepada praktek keagamaan diarahkan pada pembekalan secara personal, sosial, pedagogik dan profesional kepada para santri.

\section{PENUTUP}

Berdasarkan temuan dan analisis pembahasan di atas, maka kesimpulan penelitian ini adalah sebagai berikut, pertama pendidikan spiritualitas keagamaan moderat yang diinternalisasikan di Pesantren Amanatul Ummah Kembangbelor Pacet Mojokerto berjalan dengan baik dengan bukti adanya upaya memasukkan nilai, objektivasi proses dialog dalam diri santri dan ustadznya, serta upaya proses aktualisasi sikap dan tindakan di ruang publik. Kedua, pendidikan spiritualitas berwawasan moderat berlangsung secara signifikan, kehidupan santri diarahkan sesuai dengan citacita Islam, mengacu pada perkembangan kehidupan manusia masa depan, tanpa menghilangkan prinsip-prinsip Islam dengan berusaha menciptakan kepribadian islami demi membangun insan yang religius-nasionalis, religius-intelektualis dan intelektualreligius, sesuai dengan cita-cita Islam yang bersumber pada al-Qur'an, al-Sunnah, dan ijtihad. Ketiga, pendidikan spiritualitas berkarakter berlangsung secara optimal melalui peningkatan keimanan, pemahaman, penghayatan, dan pengamalan anak didik tentang Islam dan keislaman. Aktualisasinya dalam kehidupan bermasyarakat, berbangsa dan bernegara.

\footnotetext{
${ }^{43}$ Wawancara dengan santri Wakil kepesantren Amanatul Ummah, Ust. Abdul Halim, M.Pd, 4 Juli 2020.

${ }^{44}$ Wawancarasantri alumni, Ahmad Dofir, Alfian Nur Muhammad, Jeffa Lianto Van Bee, Varicha Fiddarain, Ahmad Julul Zamzami, Ihdan Muhammad Zaky.
} 


\section{DAFTAR RUJUKAN}

Bee, Jeffa Lianto Van., Wawancara, 11 Juli 2021.

Berger, Peter L \& Neuhauss, Richard J., To Empower People: The Role of Media-ting Structure in Public Policy. Washington: American Interpri-se Institute of Public Policy Reseach, 1977.

Bungin, Burhan. (2012). Realitas Sosial dan Konstruksi Sosial, dalam buku Metodologi

Chalim, KH. Asep Saifuddin. Wawancara, 4 Juli 2021.

Chudhari, Achmad., Wawancara, 4 Juli 2021.

Dhofier, Zamakhsyari, Tradisi Pesantren: Studi Pandangan Hidup Kyai dan Visinya Mengenai Masa Depan Indonesia. Jakarta: Pustaka LP3ES., 2011.

Djamaluddin \& Abdullah, Kapita Selekta Pendidikan Islam, (Bandung: Pustaka Setia, 1998). Dofir, Ahmad, "Strategi Kepentingan KH Asep. Saifuddin Chalim Dalam Memajukan Lembaga Pesantren", Skripsi tidak diterbitkan Universitas Islam Majapahit Mojokerto, 2016.

Dofir, Ahmad., Wawancara, 11 Juli 2021.

Ependi, A. (2008). Konsep Zikir Menurut Dr. Quraish Shihab dalam Tafsir Al Misbah, Skripsi. Jakarta: Universitas Islam Negeri Syarif Hidayatullah .

Eriyanto, Analisis Wacana: Pengantar Analisis Teks Media (Yogyakarta: LkiS, 2003.

Eriyanto. (2002). Analisis Framing: Konstruksi, Ideologi, dan Politik Media. Yogyakarta:

Fidarain, Varichah., Wawancara, 11 Juli 2021.

Geertz, Clifford. Abangan, Santri Kiai da-lam Masyarakat Jawa, terj. Aswab Mahasin. Jakarta: Pustaka Jaya, 1983.

Gibson, J., Ivancevich, J. M., \& Jr, J. H. (1985). Organisasi: Perilaku, Struktur, Proses. (Terjemahan: Agus Dharma). Jakarta: Erlangga.

Gobel, F. A. (2015). Pengaruh Pencerahan Qalbu Padang Lampe terhadap Persepsi Stres, Strategi Koping dan Jumlah CD4 Pengidap HIV/AIDS. "Disertasi". Surabaya: Fakultas Kedokteran Universitas Airlangga.

Halim, Abdul., Wawancara, 4 Juli 2021.

Heaton, D. P., Wilks, J. S., \& Travis, F. (2004). Constructs, Methods and Measures for Researching Spirituality in Organizations. Journal of Organizational Change Management, 62-76.

Herbert, B., \& Zlipper, M. K. (2000). Bebas Stres dalam 10 menit: Metode Respons Relaksasi. Bandung: Kaifa. 
Ida, Laode. NU Muda: Kaum Progressif dan Sekularisme Baru. Yogyakarta: LKiS, 2004.

Iklan Televisi dan Keputusan Konsumen serta Kritik Terhadap Peter L. Berger dan Thomas Luckmann. Jakarta: Kencana Prenada Media Group.

Irham, M. I. (2013). Rasa Ruhani Spiritualitas di Abad Modern. Bandung: Ciptapusaka Media Perintis.

Junaris, Imam. Manajemen Strategik Pengembangan Kompetensi Guru (Studi Multikasus di Sekolah Menengah Atas darul Ulum 2 Unggulan BPPT CIS ID 113 Jombang dan Madrasah Aliyah Unggulan Amanatul Ummah Program MBI di Pacet Mojokerto)." Disertasi UIN Maulana Malik Ibrahim Malang, 2016.

Kartono, K. (1994). Psikologi Sosial untuk Manajemen, Perusahaan dan Industri. Jakarta: PT Raja Grafindo Persada.

Kuntoro. (2011). Dasar Filosofi Metodologi Penelitian. Surabaya: Pustaka Melati.

Lestari, A. M. (2013, Juli 6). Nilai Spiritual Merupakan Kebutuhan Fundamental. Retrieved from http://ayumegadarmalestari.blogsport.co.id/2013/07/

Magenda, Burhan D, "Ulama dan Demokrasi di Indonesia”, Jurnal Pesantren, No. 1, Vol. IV, 1987.

Mahmood \& Khan,'Moral Development in Mystical Islamic Education in Indo-Pak Subcontinent: Sufism'. Journal of Education and Sociology, 2010

Mastuhu. "Pesantren dan Ulama Masa Datang", Jurnal Pesantren, Edisi No. 1, Vol. III, 1986.

-, Dinamika Sistem Pendidikan Pesantren: Suatu Kajian tentang Unsur dan Nilai Sistem Pendidikan Pesantren, Jakarta : INIS, 1994

Moleong, Lexy, Metodologi Penelitian Kualitatif, (Bandung: PT Remaja Rosdakarya, 2000). Patton, Qualitative Education Methods, (Bevery Hills, Sage Publications, 1980).

Mudawi, Ali Khalid, 'Islamic Education: Towards A Comprehensive View.' King Saud University., Vol. 1 Educ. Sci. $(1,2)$

Muhammad, Alfian Nur., Wawancara, 11 Juli 2021.

Muhaimin, Paradigma Pendidikan Islam, Bandung: Rosdakarya, 2001

Muhamin, A \& Mujib, A, Pemikiran Pendidikan Islam, Jakarta: Tri Genda Karya: 1993

Mujib, Fathul. Pendidikan Islam Unggul dan Kompetitif, Ikhtiar Merumuskan Strategi Keunggulan Bersaing Lembaga Pendidikan Islam Berbasis Pesantren, Tulungagung: IAIN Tulungagung Press, 2019.

Nelson, R., \& Jones. (2011). Teori dan Praktik Konseling dan Terapi. Yogyakarta: Pustaka Pelajar.

Noor, J. (2012). Metodologi Penelitian. Jakarta: Kencana Prenada Media Group.

Penelitian Kualitatif: Aktualisasi Metodologis ke Arah Ragam Varian Kontemporer. Depok: PT. Rajagrafindo Persada 
Raharjo, M. Dawam, "Kiai dalam Perubahan Sosial”, Jurnal Pesantren, Edisi No. 1, Vol. III, 1986.

Rinaldy, E. (2013). Hubungan Sholat Tahajud dengan Perubahan Kadar Kortisol dan Tingkat Stres pada Penderita HIV AIDS. Jakarta: Universitas Islam Negeri Jakarta.

Sahal Mahfudh, Nuansa Fiqih Sosial, 2004 (Yogyakarta: LKiS)

Samuel, Hanneman. Perspektif Sosiologis Peter Berger. Jakarta: Pusat Antar Universitas Bidang Ilmu-Ilmu Sosial - Universitas Indonesia, 1993.

Sari, R. K. (2015). Pengaruh Intervensi Spiritual dan Emosional (SPIEM) terhadap Perubahan Psikoneuroimunologis. Disertasi. Semarang: Universitas Diponegoro.

Shihab, Q. (2006). Wawasan Al Qur'an tentang Zikir dan Doa. Jakarta: Lentera Hati.

Shirley, T. K., \& Norazliah. (2012). Surgical Patients, Satisfactions of Nursing Care other Orthopedic Words in Hospital University Sains Malaysia. Health and the Environment Journal.

Simmons, B. (2000). Eustress at work: Accentuating the positive. Oklahoma State University: Unpublisher doctoral dissertation.

Soleh. (2006). Terapi Sholat Tahajud menyembuhkan berbagai penyakit. Jakarta: Hikmah.

Spradley, J.P Participant Observation. New York: Holt, Rinehart and Winston)1980

Stier, L. O. (2008). Sense of humor, stress and coping and outcomes in children's lives. Proquest Dissertations and theses, 1-15.

Susan, L. Douglas \& Munir, A. Syaikh, "Defining Islamic Education: Differenciation and Applications." Current Issues in Comparative Education, Vol. 7 (1)

Wahab, Abd., "Model Penguatan Madrasah Swasta (Studi Model \{Penguatan Madrasah Aliyah Amanatul Ummah Pacet dan Madrasah Aliyah Pesantren AlAmin Sooko Kabupaten Mojokerto)" Disertasi PPS Universitas 17 Agustus 1945, Surabaya, 2018.

Woodward, Mark R. Islam Jawa, Kesalehan Normatif Versus Kebatinan. Terj. Hairus Salim. Yogyakarta: LKiS, 2006.

Zakiah Daradjat, Ilmu Pendidikan Islam, Jakarta: Bumi Aksara, 1992

Zaky, Ihdan Muhammad., Wawancara, 18 Juli 2021.

Zamroni, "Strategi dan Model Implementasi Pendidikan Karakter di Sekolah", dalam Darmiyati Zuchdi, Pendidikan Karakter dalam Perspektif Teori dan Praktek (Yogyakarta: UNY Press, 2011.

Zamzami, Ahmad Julul., Wawancara, 11 Juli 2021. 